\title{
Upaya Meningkatkan Penyesuaian Diri melalui Layanan Bimbingan Klasikal dengan Teknik Permainan Edukatif
}

\author{
Durotun Mahfudzoh \\ Guru Bimbingan dan Konseling
}

SMA Negeri 1 Balapulang

Guru SMA Negeri 1 Balapulang

\begin{abstract}
Abstrak
Tujuan penelitian ini yaitu untuk mengetahui peningkatan penyesuaian diri melalui layanan bimbingan klasikal dengan teknik permainan edukatif pada siswa kelas X-MIA 3 SMA Negeri 1 Balapulang semester 2 tahun pelajaran 2018/2019. Jenis penelitian yang digunakan pada penelitian ini adalah penelitian tindakan bimbingan dan konseling (PTBK) dengan 2 siklus. Hasil siklus II, diketahui dari hasil analisa skala penyesuaian diri diperoleh data dari 3 siswa yang penyesuaian diri tergolong kategori sangat rendah, 1 orang masih berada pada kategori sangat rendah dan 2 siswa meningkat menjadi rendah dan 5 siswa pada kategori rendah, 2 siswa meningkat menjadi cukup dan 3 orang menjadi kategori baik, sedangkan 4 siswa yang pada siklus 1 berada dalam kategori cukup meningkat menjadi baik. Dari keseluruhan siklus yang dilakukan pada kegiatan layanan bimbingan klasikal di kelas X-MIA 3 SMA Negeri 1 Balapulang semester 2 tahun pelajaran 2018/2019 dapat disimpulkan dan menjawab hipotesis bahwa melalui pemberian layanan bimbingan klasikal dengan teknik permaian edukatif dapat meningkatkan penyesuaian diri siswa kelas X- MIA 3 SMA Negeri Balapulang semester 2 tahun pelajaran 2018/2019.

Kata Kunci : Layanan Bimbingan Klasikal, Penyesuaian Diri, Teknik Permainan Edukatif
\end{abstract}

\begin{abstract}
The purpose of this study is to find out the improvement in adjustments through classical guidance services with educational game techniques in class X-MIA 3 students of SMA 1 Balapulang in semester 2 of 2018/2019 academic year. This type of research used in this study is a guidance and counseling action research (PTBK) with 2 cycles. The results of the second cycle, it is known from the analysis of the adjustment scale obtained data from 3 students whose adjustment is classified as very low category, 1 person is still in the very low category and 2 students increased to low and 5 students in the low category, 2 students increased to be sufficient and 3 people are in the good category, while 4 students in the first cycle are in the sufficiently increased category to be good. From the whole cycle carried out in classical guidance service activities in class X-MIA 3 of SMA 1 Balapulang semester 2 of 2018/2019 academic year it can be concluded and answered the hypothesis that through the provision of classical guidance services with educational application techniques can increase the adjustment of students of class X- MIA 3 SMA 1 Balapulang semester 2 of the 2018/2019 school year.
\end{abstract}

Keywords: Classical Guidance Services, Self-Adjustment, Educational Game Techniques 


\section{PENDAHULUAN}

Manusia diciptakan oleh Tuhan Yang Kuasa sebagai makhluk sosial tidak bisa hidup tanpa bantuan orang lain. Mereka saling membutuhkan antara satu sama lainnya dalam memenuhi kebutuhan hidup. Dalam hidup bersama perlu adanya suatu aturan atau norma yang diharapkan dapat membawa individu menjadi lebih baik demi mempertahankan hidup yang diterima oleh lingkungannya.

Untuk dapat diterima oleh lingkungannya, setiap individu harus memiliki penyesuaian diri, sebab apabila individu tidak dapat menyesuiakan diri maka tidak dapat mencapai kehidupan yang harmonis antara individu dengan lingkungannya. Jadi penyesuaian diri merupakan salah satu faktor yang sangat penting dalam kehidupan manusia, demikian pentingnya sampai ada pernyataan bahwa "hidup manusia sejak lahir sampai mati tidak lain adalah untuk penyesuaian" (Gunarso, 1995: 51).

Kemampuan penyesuaian diri mulai sangat diperlukan saat manusia memasuki masa remaja karena masa remaja merupakan masa yang penuh gejolak sehingga remaja sering dihadapkan pada persoalanpersoalan yang kompleks yang menjadi permasalahan yang dirasakan sulit oleh para remaja. Hurlock mengemukakan bahwa "tugas perkembangan remaja yang paling sulit bagi remaja yaitu berhubungan dengan penyesuaian sosial", adapun salah satu penyesuaian sosial remaja yaitu penyesuaian dengan lingkungan sekolah. Siswa SMA yang tergolong dalam usia remaja, mengalami proses perkembangan dan pertumbuhan serta mempunyai kecenderungan kurang stabil secara psikis banyak mengalami kesulitan dalam menyesuaikan diri, entah apa yang menjadi sumber utama dari kesulitan menyesuaikan diri, dampaknya yang negatif akan tampak dalam prestasi belajar yang kurang memuaskan.

Winkel (2004:238) mengemukakan "gejala-gejala yang dapat memberikan indikasi mengenai kesulitan dalam menyesuaikan diri, antara lain: perilaku membangkang, mudah tersinggung, suka membolos, suka menyinggung perasaan orang lain dan suka berbohong".

Sekolah merupakan salah satu tempat pendidikan bagi siswa untuk dapat mengembangkan diri melalui layanan bimbingan dan konseling. Bimbingan dan konseling memiliki beberapa layanan yang merupakan kegiatan bantuan dan tuntunan yang diberikan kepada individu pada umumnya dan siswa sekolah pada khususnya dalam rangka meningkatkan mutunya. Beberapa layanan dalam bimbingan dan konseling sudah diberikan kepada mereka termasuk layanan bimbingan klasikal, namun demikian hasilnya belum maksimal.

Berdasarkan hasil observasi dan wawancara dengan beberapa guru mata pelajaran bahwasanya siswa kelas X-MIA 3 SMA Negeri 1 Balapulang tahun pelajaran 2018/2019 hampir 50\% siswanya masih memiliki penyesuaian diri yang rendah. Dari data tersebut dapat disimpulkan bahwa siswa kelas X-MIA 3 SMA Negeri 1 Balapulang tahun pelajaran 2018/2019 perlu ditingkatkan penyesuaian dirinya, dengan meminimalkan siswa yang menunjukkan sikap dan perilaku yang menggambarkan siswa memiliki penyesuaian diri yang rendah.

Layanan bimbingan klasikal dengan teknik permainan edukatif adalah salah satu layanan dasar dalam bimbingan dan konseling komprehensif berupa proses pemberian bantuan kepada seluruh siswa melalui kegiatan penyiapan pengalaman terstruktur secara klasikal dengan menggunakan teknik permainan edukatif.

Permainan edukatif yaitu suatu kegiatan yang sangat menyenangkan dan dapat merupakan cara atau alat pendidikan yang bersifat mendidik dan bermanfaat untuk meningkatkan kemampuan berbahasa, berpikir serta bergaul dengan lingkungan atau untuk menguatkan dan menterampilkan anggota badan si anak, mengembangkan kepribadian, mendekatkan hubungan antara pengasuh dengan pendidik (anak didik), kemudian menyalurkan kegiatan anak didik dan sebagainya.

Menurut Iva Rifa (2012:27) mengemukakan bahwa tidak semua permainan dapat dikategorikan sebagai permainan edukatif. Nilai edukatif itu bisa didapatkan bila ada hal-hal yang bermanfaat bagi penggunanya. Permainan itu dikatakan edukatif apabila (1) harus mampu mengembangkan aspek kognitif, afektif dan psikomotor, (2) Multifungsi, penggabungan dari dua atau seluruh ranah tersebut, (3) tujuan permainan itu jelas memiliki nilai edukatif (4) melatih konsep dasar. 
Menurut Suwarjo dan Eva (2010:20) permainan dalam Bimbingan dan Konseling dapat dibagi dalam 4 katagori, yaitu : (1) Permainan tanpa media dalam bentuk permainan individu (2) Permainan dengan menggunakan media sederhana dalam bentuk permainan individu (3) Permainan dengan menggunakan media dan dilaksanakan dalam bentuk permainan kelompok (4) Permainan dengan menggunakan media dalam bentuk permainan kelompok yang dikompetisikan.

Tujuan penelitian ini yaitu untuk mengetahui peningkatan penyesuaian diri melalui layanan bimbingan klasikal dengan teknik permainan edukatif pada siswa kelas X-MIA 3 SMA Negeri 1 Balapulang semester 2 tahun pelajaran 2018/2019.

\section{METODE}

Jenis penelitian yang digunakan pada penelitian ini adalah penelitian tindakan bimbingan dan konseling (PTBK). Menurut Imam Tadjri (2014) penelitian tindakan bimbingan dan konseling memiliki karakteristik yaitu merupakan penelitian kolaboratif, suatu penelitian kerjasama antara konselor dengan teman sejawatnya dimana mereka bekerja. Teknik analisa data yang digunakan adalah analisis kualitatif dengan cara membandingkan data hasil skala psikologi dan observasi sebelum pemberian tindakan, setelah siklus I dan siklus II. Penyesuaian diri pada kondisi awal diperoleh dari keadaan siswa sebelum dilakukan penelitian, data tersebut diperoleh dari hasil skala psikologi yang diisi oleh siswa dan hasil observasi saat siswa mengikuti kegiatan layanan bimbingan dan konseling oleh guru pembimbing serta masukan dari guru mata pelajaran yang diperoleh pada saat kegiatan pembelajaran. Data yang diperoleh melalui skala psikologi dan hasil observasi tersebut akan dibandingkan dengan data yang diperoleh setelah kegiatan layanan bimbingan klasikal dengan teknik permainan edukatif pada siklus I dan siklus II dengan melakukan refleksi pada setiap siklus kegiatan.

\section{HASIL}

Kondisi awal sebelum dilaksanakan penelitian tindakan bimbingan dan konseling, peneliti melakukan proses pembimbingan awal kepada siswa kelas X- MIA 3 SMA Negeri 1 Balapulang pada semester 2 tahun pelajaran 2018/2019, terbukti masih banyak muncul perilaku siswa yang menunjukan bahwa siswa tersebut memiliki penyesuaian diri yang rendah seperti : masuk kelas terlambat, tidak mengerjakan PR, berbicara sendiri saat diajar, melamun saat pelajaran, tidak konsentrasi, membuat gaduh, menyontek, terlambat menyerahkan tugas, selain itu berdasarkan hasil analisa dari skala psikologi tentang penyesuaian diri dan hasil observasi diperoleh data bahwa masih ada 12 siswa $(33,33 \%)$ dari 36 siswa memiliki penyesuaian diri sangat rendah, 6 siswa $(16,67 \%)$ memiliki penyesuaian diri yang rendah, 5 siswa $(13,89 \%)$ memiliki penyesuain diri yang cukup, 6 siswa (16,67\%) yang memiliki penyesuain diri yang baik dan 7 siswa $(19,44 \%)$ yang memiliki penyesuaian diri sangat baik.

Siklus I

Layanan bimbingan klasikal dengan teknik permainan edukatif pada siklus I ini dilaksanakan dalam 3 kali pertemuan. Pertemuan pertama dalam bentuk permainan tanpa menggunakan media dan dilaksanakan secara individu di dalam kelas. Pertemuan kedua dalam bentuk permainan dengan menggunakan media dan dilaksanakan secara individu. Pertemuan ketiga dalam bentuk permainan dengan menggunakan media dan dilaksanakan secara individual.

Hasil analisis skala dapat diketahui bahwa 18 siswa yang memiliki penyesuaian diri yang rendah, 3 siswa penyesuaian dirinya masih berada pada kategori sangat rendah namun skornya sudah meningkat dan 5 siswa berada pada posisi/ kategori rendah dan 10 siswa berada pada kategori cukup. Sedangkan hasil pengamatan yang dilakukan oleh kolaborator/ guru mata pelajaran pada saat 18 siswa tersebut mengikuti pelajaran diketahui bahwa terdapat tidak munculnya perilaku-perilaku tertentu, 3 siswa menunjukan perilaku penyesuaian diri yang sangat rendah, 5 siswa menunjukkan perilaku penyesuaian diri yang rendah dan 10 siswa sudah menunjukkan perilaku penyesuaian diri yang cukup. 
Pada pelaksanaan kegiatan layanan bimbingan klasikal dengan teknik permainan edukatif pada siklus ini, guru bimbingan konseling peneliti masih merasakan bahwa antusias siswa belum maksimal karena masih dilaksanakan secara individu, oleh karena itu pada siklus berikutnya akan dilaksanakan kegiatan layanan bimbingan klasikal dengan teknik permainan edukatif dalam bentuk kelompok.

Siklus II

Bimbingan klasikal dengan teknik permainan edukatif pada siklus II dilaksanakan untuk memberikan layanan kepada 36 siswa, termasuk 3 siswa yang pada siklus I penyesuaian dirinya masih pada kategori sangat rendah, 5 siswa dalam kategori rendah dan 11 siswa dalam kategori cukup, dalam bentuk permainan dengan menggunakan media yang dilaksanakan secara kelompok.

Berdasarkan hasil skala psikologis ada 18 siswa yang memiliki penyesuaian diri yang rendah, 1 siswa penyesuaian dirinya berada pada posisi/kategori sangat rendah, 2 siswa berada pada posisi/kategori rendah, 2 siswa berada pada posisi/kategori cukup dan 13 siswa berada pada posisi/ kategori baik. Sedangkan hasil pengamatan yang dilakukan oleh kolaborator/guru mata pelajaran pada saat 18 siswa tersebut mengikuti pelajaran diketahui bahwa tidak munculnya perilaku-perilaku tertentu yang menunjukkan perilaku penyesuaian diri yang rendah yaitu : 1 siswa tidak muncul 11 perilaku, 1 siswa tidak muncul 8 perilaku, 1 siswa tidak muncul 9 perilaku, 1 siswa tidak muncul 7 perilaku, 1 siswa tidak muncul 5 perilaku, 3 siswa muncul 9 perilaku, 5 siswa muncul 10 perilaku dan 5 siswa muncul 11 perilaku.

Penyelenggaraan kegiatan layanan bimbingan klasikal dengan teknik edukatif pada siklus II dapat dikatakan berhasil untuk meningkatkan penyesuaian diri, hal tersebut ditunjukan dengan meningkatnya antusias siswa dalam proses pelakanaan kegiatan layanan dan meningkatnya penyesuaian diri siswa sebagaimana ditujukan dalam hasil observasi di lapangan.

\section{PEMBAHASAN}

Berdasarkan hasil analisa dari skala penyesuaian diri siswa setelah diberikanya layanan bimbingan klasikal dengan teknik permainan edukatif pada siklus I menunjukan bahwa 12 siswa yang memiliki penyesuaian diri yang sangat rendah, 3 siswa penyesuaian dirinya masih berada pada kategori sangat rendah namun skornya meningkat dan 5 siswa berada pada posisi/ kategori rendah dan 4 siswa meningkat berada pada kategori cukup serta 6 siswa yang dalam kategori rendah meningkat menjadi pada kategori cukup.

Dari hasil observasi guru mata pelajaran saat mengikuti pelajaran menunjukan bahwa siswa -siswa yang menunjukan perilaku memiliki penyesuaian diri yang rendah makin berkurang dan berubah menjadi perilaku yang menunjukan meningkatnya penyesuaian diri yang semakin baik. 3 siswa menunjukan perilaku penyesuaian diri yang sangat rendah, 5 siswa menunjukkan perilaku penyesuaian diri yang rendah dan 4 siswa sudah menunjukkan perilaku penyesuaian diri yang cukup. Ketidak munculan itu mencapai rata- rata 6 dari 13 perilaku yang menunjukan perilaku penyesuaian diri yang rendah. Hal ini menunjukan bahwa setelah dilaksanakanya layanan bimbingan klasikal dengan teknik permainan edukatif, 12 siswa yang penyesuaian dirinya sangat rendah meningkat penyesuaian dirinya menjadi rendah dan cukup.

Pada hasil observasi saat kegiatan layanan berlangsung diperoleh data bahwa siswa yang pada awal kegiatan masih tampak kaku dan ragu setelah mengikuti kegiatan layanan bimbingan klasikal dengan teknik permainan edukatif menjadi lebih kondusif, bersemangat antusias mengikuti kegiatan, bahkan ada rasa enggan untuk mengakhiri kegiatan.

Pada kegiatan bimbingan klasikal siklus II, diketahui bahwa dari hasil analisa skala penyesuaian diri diperoleh data dari 3 siswa yang penyesuaian dirinya kategori sangat rendah, 1 orang masih berada pada kategori sangat rendah dan 2 siswa meningkat menjadi rendah dan 5 siswa pada kategori rendah 2 siswa meningkat menjadi cukup dan 3 orang menjadi kategori baik, sedangkan 4 siswa yang pada siklus 1 berada dalam kategori cukup meningkat menjadi baik.

Hasil observasi dari guru mata pelajaran setelah dilaksanakanya layanan bimbingan klasikal dengan teknik permainan edukatif didapatkan bahwa 1 siswa tidak muncul 11 perilaku, 1 siswa tidak muncul 8 perilaku, 1 siswa tidak muncul 9 perilaku, 1 siswa tidak muncul 7 perilaku, 1 siswa tidak muncul 5 perilaku, 3 siswa muncul 9 perilaku, 5 siswa muncul 10 perilaku dan 5 siswa muncul 11 perilaku. 
Dari hasil observasi yang dilakukan pada saat kegiatan layanan bimbingan klasikal berlangsung diperoleh gambaran bahwa setelah kegiatan berlangsung kondisi siswa sangat kondusif, sangat bersemangat, dalam proses kegiatan layanan bimbingan klasikal siswa sangat antusias, dan pada saat mengakhiri kegiatan layanan bimbingan klasikal siswa merasa mendapatkan sesuatu manfaat yang sangat berharga untuk meningkatkan penyesuaian diri.

\section{SIMPULAN}

Dari keseluruhan siklus yang dilakukan pada kegiatan layanan bimbingan klasikal di kelas XMIA 3 SMA Negeri 1 Balapulang semester 2 tahun pelajaran 2018/2019 dapat disimpulkan dan menjawab hipotesis bahwa melalui pemberian layanan bimbingan klasikal dengan teknik permaian edukatif dapat meningkatkan penyesuaian diri siswa kelas X- MIA 3 SMA Negeri Balapulang semester 2 tahun pelajaran 2018/2019.

\section{SARAN}

Saran-saran yang dapat peneliti sampaikan dalam penelitian ini sebagai berikut: 1) Kepada guru bimbingan dan konseling yang akan melaksanakan penelitian tindakan bimbingan dan konseling untuk dapat mengembangkan teknik-teknik permainan edukatif yang lain sehingga akan diperoleh khasanah pengetahuan dan pemahaman yang lebih luas dalam rangka meningkatkan profesionalisme guru bimbingan dan konseling, 2) Kepada Kepala sekolah selaku manajemen sekolah agar berupaya semaksimal mungkin untuk memberikan kesempatan kepada guru bimbingan dan konseling meningkatkan profesionalisme khususnya melalui kegiatan penelitian tindakan bimbingan dan konseling, 3) Kepada guru mata pelajaran untuk dapat memanfaatkan hasil penelitian tindakan bimbingan dan konseling dalam rangka meningkatkan proses kegiatan pembelajaran, sehingga dapat meningkatkan hasil belajar siswa secara optimal.

\section{DAFTAR PUSTAKA}

Gunarso, Singgih.1995. Psikologi Perkembangan. PBk Gunung Mulia

Rifa, Iva. 2012. Koleksi Games Edukatif di Dalam dan Luar Sekolah. Yogyakarta :Penerbit Flash Books

Suwarjo dan Imania, E. 2010. 55 Permainan (games) dalam Bimbingan dan Konseling. Yogyakarta: Penerbit Paramitra Publishing.

Tadjri, Imam. 2014. Penelitian Tindakan Bimbingan \& Konseling. Semarang : Penerbit Widya Karya.

Winkel, WS. 2004. Bimbingan dan Konseling di Institusi Pendidikan. Yogyakarta: Penerbit Media Abadi. 